Nadine Cloete

Nadine Cloete, is a South African filmmaker; her most recent project is Action Kommandant, a documentary based on the life of slain liberation fighter, Ashley Kriel. Email: cloete.nadine@gmail.com

\section{Tribute \\ Zulfah Otto-Sallies: an open door; an open heart}

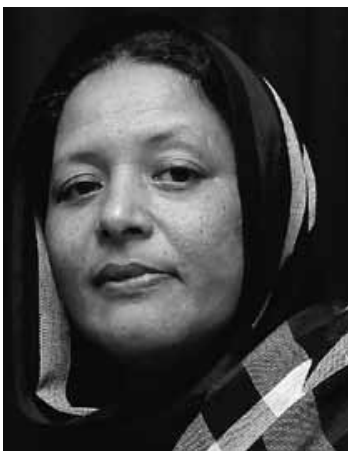

Filmmaker, poet, director, playwright, author, Zulfah OttoSallies was born on 8 May 1961 and passed away on 8 July 2016 after suffering a stroke.

Zulfah was born in Port Elizabeth and grew up in the Bo-Kaap, Cape Town. She may be best known for her novella, Diekie van die Bo-Kaap (Tafelberg, 1997), which has been performed as an immensely successful play and was set as a popular prescribed school work. She worked in various film genres and her film titles include Through my Daughters Eyes, Raya and Don't Touch.

Zulfah's father was a member of one of the Malay choirs in Bo-Kaap and at the age of 13 she started writing lyrics for them. She won awards for her songs. She saw writing lyrics as a way of telling stories. Zulfah went on to earn a Masters degree in Visual Arts/Multi-Media and Theatre at Das Arts in Amsterdam, The Netherlands.

The Bo-Kaap community played a huge role in Zulfah's development as an artist: I grew up in a society that was culturally very strong. The Cape Malay identity was engrained into our psyche it gave us a sense of belonging and assurance that our culture was an important one [...] The Cape Malay culture for me meant very much there is a time and place for everything. New Year's Eve meant standing in Wale Street watching the Malay choirs' parade. 2nd New Year saw the Cape Minstrels parade. (Ellerson)

I was introduced to Zulfah's work as a film student at the University of Cape Town. The first film of hers that I saw was Raya. I immediately felt that it had been created by someone so in tune with the community. It was complex and intimate. I researched more about Zulfah and just knowing a little more about her, gave a sense of hope. Prior to hearing about her I did not know about any woman of colour working in film. She was authentic in every way-in her being and in her art.

In our third year we could choose our supervisors from a list of filmmakers UCT was affiliated with. I do not need to describe my feelings when I saw Zulfah's name on that list. I said to my group this is the person we must work with. The group consisted of me, Antoinette Engel and Victoria Miller. We had our first meeting 
outside on the Arts Block and Zulfah arrived, wearing her scarf, down to earth, ready to work. I sat in awe for a while. We had delegated roles and I was going to be the cameraperson. Zulfah then said that I could come to her house and use her camera to practice.

Shahied, Zulfah's husband, set up the camera for me upon arrival at their BoKaap home. I then filmed their neighbours. The first lesson Zulfah taught me was to follow energy: to learn how to be in tune with peoples' energies and just follow it.

Another thing about being in the Sallies' family house was that there were always so many people coming and going, in and out, for a while I thought Zulfah must have ten children! There were so many youth coming and going, in and out of that always-open-door and Zulfah spoke to everyone in the same way so it seemed she had many children, but in a way, of course she did.

She was the definition of selflessness in the way she wanted youth to succeed. Zulfah was there when my UCT lecturers couldn't understand the Afrikaans in my films. Zulfah was there when there was no structure in Jitsvinger: Maak it Aan. Zulfah sat in the edit suite at UCT with me until midnight when she was no longer employed by UCT. Zulfah was the first person to call me a filmmaker. Zulfah was there before and when I received funds for Action Kommandant. Zulfah opened the door when I just showed up because I had lost her phone number...

There are others whose lives Zulfah touched: Paulette Fortuin wrote in her blog that Zulfah's practice of "only" telling the stories of "her culture and where she grew up" touch her very much for through her lens the old ways of the Bo-Kaap were recorded and introduced to a younger generation (see also Palitza). The filmmaker Oliver Hermanus, the director of Shirley Adams, Skoonheid and The Endless River, wrote on Zulfah's role in the awakening of his art:

I was 14 years old, dying to have a movie camera and make my own films but unable to afford one. My mother saw an ad for a Women's Film Festival being held at the Artscape in Cape Town. She took me and I saw my first Zulfah Otto-Sallies film. I was so nervous but went over and spoke to her afterwards, asking if I could hang out with her or watch her work or do anything just to be near filmmaking. She let me come to her house in Bo Kaap and visit her on the set of her next work. She introduced me to her writing partner who agreed for me to visit him every Thursday for an hour after school. I went straight home and started writing my first feature, Shirley Adams. She lit the spark for me.

I was immensely saddened by the news of Zulfah's passing. She may no longer be with us in a physical sense, but I stand proud that I experienced someone like her. I feel one of the biggest lessons she leaves us all with is to pass on our talents and to up-skill others. My thoughts and prayers are still with her husband and three children. 


\section{Works Cited}

Cloete, Nadine. Action Kommadant. 2016. 26 Jul 2016. < http://actionkommandant.co.za>.

Ellerson, Beti. "Zulfah Otto Sallies: Filming the Bo-Kaap Culture of South Africa." African Women in Cinema. 11 Oct 2011. 26 Jul 2016. <http://africanwomenincinema.blogspot.co.za/2011/10/zulfahotto-sallies-filming-bo-kaap.html $>$.

Fortuin, Paulette. "Meeting Zulfah Otto-Sallies." 5 Feb 2013. 26 Jul 2016. < http://lettadiaries.blogspot. co.za>.

Hermanus, Oliver. Post. www.facebook.com. 8 Jul 2016. 26 Jul 2016. < https://www.facebook.com/oliver. hermanus.7/posts/10104725192288607?pnref=story $>$.

Palitza, Kristin, Zulfah Otto-Sallies, Dorothy Meck, Tsitsi Dangarembga. “If We Don't Tell Our Stories, Nobody Will." Agenda 69 (2006): 152-7. 
